\title{
LEGIBILIT
}

$-$

A major purpose of the Technical Information Center is to provide the broadest dissemination possible of information contained in DOE's Research and Deveiopment Reports to business, industry, the academic community, and federal, state and local governments.

Although a small portion of this repor: is not reproducible, it is being made available to expedite the availability of information on the research discussed herein. 
$\gamma$

oAK RIDGE MATIONAL LABORATORY

MARTIN MARIETTA
Reroivad th:

MAR 201989

\author{
RESULTS OF THE \\ RADIOLOGICAL SURVEY \\ AT \\ ESSEX STREET AND \\ STATE ROUTE 17 (MJ036), \\ MAYWOOD, NEW JERSEY
}

\author{
R. D. Foley \\ J. W. Crutcher \\ R. F. Carrier \\ L. M. Floyd
}


This ieport was prepared as an account of wotk sponsored by an agency of the Lnited States Governmeat. Neither the United States Government nor any agency thereof. nor any of 'teir employees, makes any warranty, express or implie 1 , or assumes any legal liability or responsibility for the accuracy, completeness, or usefulness of any information, apparatus, product, or process disclosed, or represent that its use would not infringe privately owned rights. Reference herein to any sperific commescial product. process, or seryice by trate name, trademark, manufacturer. or otherwise, does not necessarily constitute or imply its endorsement, recommendation, or tavoring by tie United States Government or any agency thereot. The views and opinions of authore expressed herein do not necessarily state or reflect those of the United States Government or any agenry thereot. 
Nuclear and Chemical Waste Programs

(Activity No. AH 1005 00 0; ONLWCO1)

\section{RESULTS OF THE RADIOLOGICAL}

\section{SURVEY AT ESSEX STREET AND STATE ROUTE 17 (MJ036),} MAYWOOD, NEW JERSEY

R. D. Foley, J. W. Crutcher, R. F. Carrier, and L. M. Floyd

Date of Issue - February 1989

Investigation Team

R. E. Swaja - Measurement Applications and Development Manager

W. D. Cottrell - FUSRAP Project Director

R.D. Foley - Field Survey Supervisor

Survey Team Members

A. C. Butler

M. E. Ward*

W. Winton

*Stnne Associates

Work performed by the

MEASUREMENT APPLICATIONS AND DEVELOPMENT GROUP

Prepared by the

OAK RIDGE NATIONAL LABORATORY

Oak Ridge, Tennessee 37831-6285

operated by

MARTIN MARIETTA ENERGY SYSTEMS, INC.

for the

U. S. DEPARTMENT OF ENERGY

under Contract No. DE-AC05-840R21400

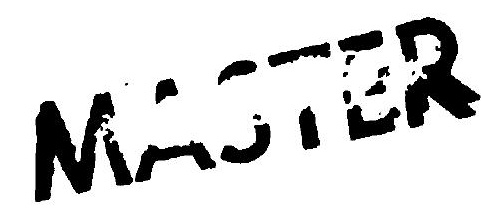




\section{CONTENTS}

LIST OF FIGURES . . . . . . . . . . . . . . . . . . . . v v

LIST OF TABLES . . . . . . . . . . . . . . . . . . vii

ACKNOWLEDGMENTS ..................... ix

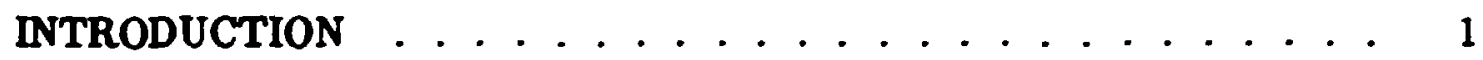

SURVEY METHODS . . . . . . . . . . . . . . . . . . . 2

SURVEY RESULTS . . . . . . . . . . . . . . . . . . . . . . 2

Surface Gamma Radiation Levels . . . . . . . . . . . . . . 2

Systematic and Biased Soil Samples . . . . . . . . . . . . . . . 3

SIGNIFICANCE OF FINDINGS ................... . . 3

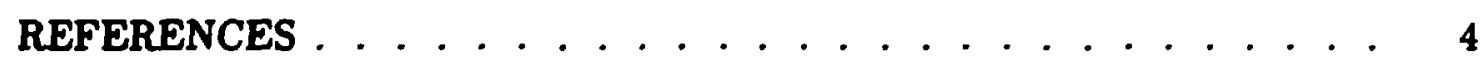




\section{LIST OF FIGURES}

1 Gamma radiation levels $(\mu \mathrm{R} / \mathrm{h})$ measured on the surface at Essex Street and State Route 17, Maywood, New Jersey (MJ036) . . . . . . . . . 5

2 Diagram showing locations of soil sar, les taken at Essex Street and State Route 17, Maywood, New Jersey (MJ036) . . . . . . . . 6 
LIST OF TABLES

1 Applicable guidelines for protection against radiation $\ldots \ldots \ldots$

2 Background radiation levels for the northern New Jersey area $\ldots \ldots \ldots$

3 Concentrations of radionuclide in soil at Essex Street and State Route 17, Maywood, New Jersey (MJ036) . . . . . . . . 8

vii 


\section{ACKNOWLEDGMENTS}

Research for this project was sponsored by the Division of Facility and Site Decommissioning Projects, U.S. Department of Energy, under Cuntract No. DE-AC05-840R21400 with Martin Marietta Energy Systems, Inc. The authors wish to acknowledge the support of J. E. Baublitz, Deputy Director, Office of Remedial Action and Waste Technology; J. J. Fiore, Director, Division of Facility and Site Decommissioning Projects; and members of their staff. The authors also appreciate the contributions of B. C. Littleton and L. J. Jeffers of IR\&A Publications Office, B. S. Ellis, D. A. Roberts, and T. R. Stewart of the Environmental Assessments group, and M. E. Ward of Don Stone Associates for participation in the collection, analyses, and reporting of data for this survey. 


\section{RESULTS OF THE RADIOLOGICAL \\ SURVEY AT ESSEX STREET AND STATE ROUTE 17 (MJ036), \\ MAYWOOD, NEW JERSEY*}

\section{INTRODUCTION}

From 1916 to 1956, process wastes and residues associated with the production and refining of thorium and thorium compounds from monazite ores were generated by the Maywood Chemical Works (MCW), Maywood, New Jersey. During the latter part of this period, MCW supplied rare earth metals and thorium compounds to various government agencies. In the $1940 \mathrm{~s}$ and $1950 \mathrm{~s}, \mathrm{MCW}$ produced thorium and lithium, under contract, for the Atomic Energy Commission (AEC). These activities ceased in 1956, and approximately three years later, the 30-acre real estate was purchased by the Stepan Company. The property is located at 100 Hunter Avenue in a highly developed area in Maywood and Rochelle Park, Bergen County, New Jersey.

During the early years of operation, MCW stored wastes and residues in lowlying areas west of the processing facilities. In the early 1930s, these areas were separated from the rest of the property by the construction of New Jersey State Highway 17. The Stepan property, the interim storage facility, and several vicinity properties have been designated for remedial action by the Department of Energy (DOE).

The waste produced by the thorium extraction process was a sandlike material containing residual amounts of thorium and its decay products, with smaller quantities of uranium and its decay products. During the years 1928 and 1944 to 1946, area residents used these process wastes mixed with tea and cocoa leaves as mulch in their lawns and gardens. In addition, some of the contaminated wastes were apparently eroded from the site into Lodi Brook ind carried downstream.

Lodi Brook is a sriall stream flowing south from Maywood with its headwaters near the Stepan wast: storage site. Approximately $150 \mathrm{ft}$ after passing under State Route 17, the stream has been diverted underground through concrete or steel culverts until it merges with the Saddle River in Lodi. New Jersey. Only a small section near Interstate 80 remains uncovered. From the 1940 s to the 1970 s when the stream was being diverted underground, its course was a ered several times. Some of these changes resulted in the movement of contaminated soil to the surface of a few properties, where it is still in evidence. In other instances, the contaminated soil was covered over or mixed with clean fill, leaving no immediate evidence on the surface. Therefore, properties in question may be $d$ illed in search of former stream bed material, even in the absence of surface contamination. Lodi Brook is now located near the west boundary of the property discussed in this report.

As a result of the Esergy and Water Appropriations Act of Fiscal Year 1984, the property discussed in this report and properties in its vicinity contaminated with residues from the former $M C W$ were included as a decontamination research and development project under the DOE Formerly Utilized Sites Remedial Action

* The survey was performed by members of the Measurement Applications and Development Group of the Health and Safety Research Division at Oak Ridge National Laboratory under DOE contract DE-AC05-84OR21400. 
Program As part of this project, DOE is conducting radiological surveys in the vicinity of the site to identify properties contaminated with residues derived from the MCW. The principal radiomuclide of concern is thorium-232. The radiological survey discussed in this report is part of that effort and was conducted, at the request of DOE, by members of the Measurement Applications and Deveiopment Group of the Oak Ridge National Laboratory.

A radiological survey of the commercial property at Essex Street and State Route 17, Maywood, New Jersey, was conducted during 1987. The survey and sampling of the ground surface and subsurface were carried out on September 2, 1987.

\section{SURVEY METHODS}

The radiological survey of the property included a gamma scan of the entire property outdoors and collection of surface and subsurface soil samples. No indoor survey measurements were performed.

U.ing a portable gamma scintillation meter, ranges of measurements were recorded for areas of the property surface. Systematic soil samples were then obtained at randomly selected locations irrespective of gamma exposure rates. In addition, biased soil samples were collected in areas of elevated gamma levels. These survey methods followed the plan outlined in Reference 1. A comprehensive description of the survey methods and instrumentation is presented in Procedures Manual for the ORNL Radiological Activities (RASA) Program, Oak Ridge National Laboratory, ORNL/TM-8600 (April 1987). ${ }^{2}$

\section{SURVEY RESULTS}

Applicable federa! guidelines are summarized in Table $1 .^{3}$ The normal background radiation ievels for the northern New Jersey area are presented in Table 2. These data are provided for comparison with survey results presented in this section. All direct measurement results presented in this report are gross readings; background radiation levels have not been subtracted. Similarly, background concentrations have not been subtracted from radionuclide concentrations measured in environmental samples.

\section{Surface Gamma Radiation Levels}

Gamma radiation levels measured during a gamma scan of the surface of the property are given in Fig. 1. Gamma exposure rates over the major portion of the property ranged from 7 to $11 \mu \mathrm{R} / \mathrm{h}$. Areas of elevated gamma readings (shaded areas in Fig. 1.) were found near the northwest corner of the building $(15-54 \mu \mathrm{R} / \mathrm{hr})$ and south of the building $(15-49 \mu \mathrm{R} / \mathrm{h})$, with several small hot spots occurring on the front lawn between the building and the parking area. 


\section{Systematic and Biased Soil Samples}

Four systematic soil samples (S1A-S2B) and thirteen biased soil samples (B1AB5C) were taken for radionuclide analyses. The samples were taken at 15-cm increments from depths of 0 to $30 \mathrm{~cm}$ for the systematic samples and from depths of 0 to $45 \mathrm{~cm}$ for the biased samples. Locations of the samples are shown in Fig. 2, with results of laboratory analyses provided in Table 3 . Concentrations of ${ }^{226} \mathrm{Ra}$ and ${ }^{232} \mathrm{Th}$ in the systematic samples ranged from 0.53 to $1.1 \mathrm{pCi} / \mathrm{g}$ and from 0.92 to $4.4 \mathrm{pCi} / \mathrm{g}$, respectively. In the biased samples, concentrations ranged from 1.1 to $6.0 \mathrm{pCi} / \mathrm{g}$ for ${ }^{226} \mathrm{Ra}$ and from 2.3 to $61 \mathrm{pCi} / \mathrm{g}$ for ${ }^{232} \mathrm{Th}$. The DOE guideline for ${ }^{232} \mathrm{Th}$ concentration in surface soil is exceeded in the five biased surface samples (B1-5), and the guideline for subsurface soil is exceeded in two biased samples (B3B and B5B). Radium-226 concentration in surface soil exceeded the DOE guideline in one sample (B5A), and the other biased samples were slightly elevated above background for the northern New Jersey area (Table 2) but are below DOE guidelines.

\section{SIGNIFICANCE OF FINDINGS}

Measurements taken at Eosex Street and State Route 17 indicate that the property contained radioactive contamination primarily from the ${ }^{232} \mathrm{Th}$ decay chain, witk some contamination from ${ }^{226} \mathrm{Ra}$. These radionuclide distributions are typical of the type of material originating from the processing operations at the MCW. The concentration and extent of ${ }^{232} \mathrm{Th}$ on this property are in excess of the applicable DOE criteria (Table 1). This material was fuund in the locations shown in Fig. 2 at sample locations B1-5. Based on the results of this radiological assessment, it is recommended that this site be considered for inclusion in the DOE remedial action program. 


\section{REFERENCES}

1. W. D. Cottrell, ORNL, to A. J. Whitman, DOE/HQ, correspondence, "Radiological Survey of Private Properties in Lodi, New Jersey" (August 15, 1984).

2. T. E. Myrick, B. A. Berven, W. D. Cottrell, W. A. Goidsmith, and F. F. Haywood, Procedures Manual for the ORNL Radiological Survey Activities (RASA) Program, Oak Ridge National Laboratory, ORNL/TM-8600 (April 1987).

3. U.S. Department of Energy, Guidelines for Residual Radioactivity at Formerly Utilized Sites, Remedial Action Prajram and Remote Surplus Facilities Management Program Sites (Rev. 2, March 1987).

4. T. E. Myrick and B. A. Berven, State Background Radiation Levels: Results of Measurements Taken During 1975-1979, Oak Ridge National Laboratory, ORNL/TM-7343 (November 1981). 


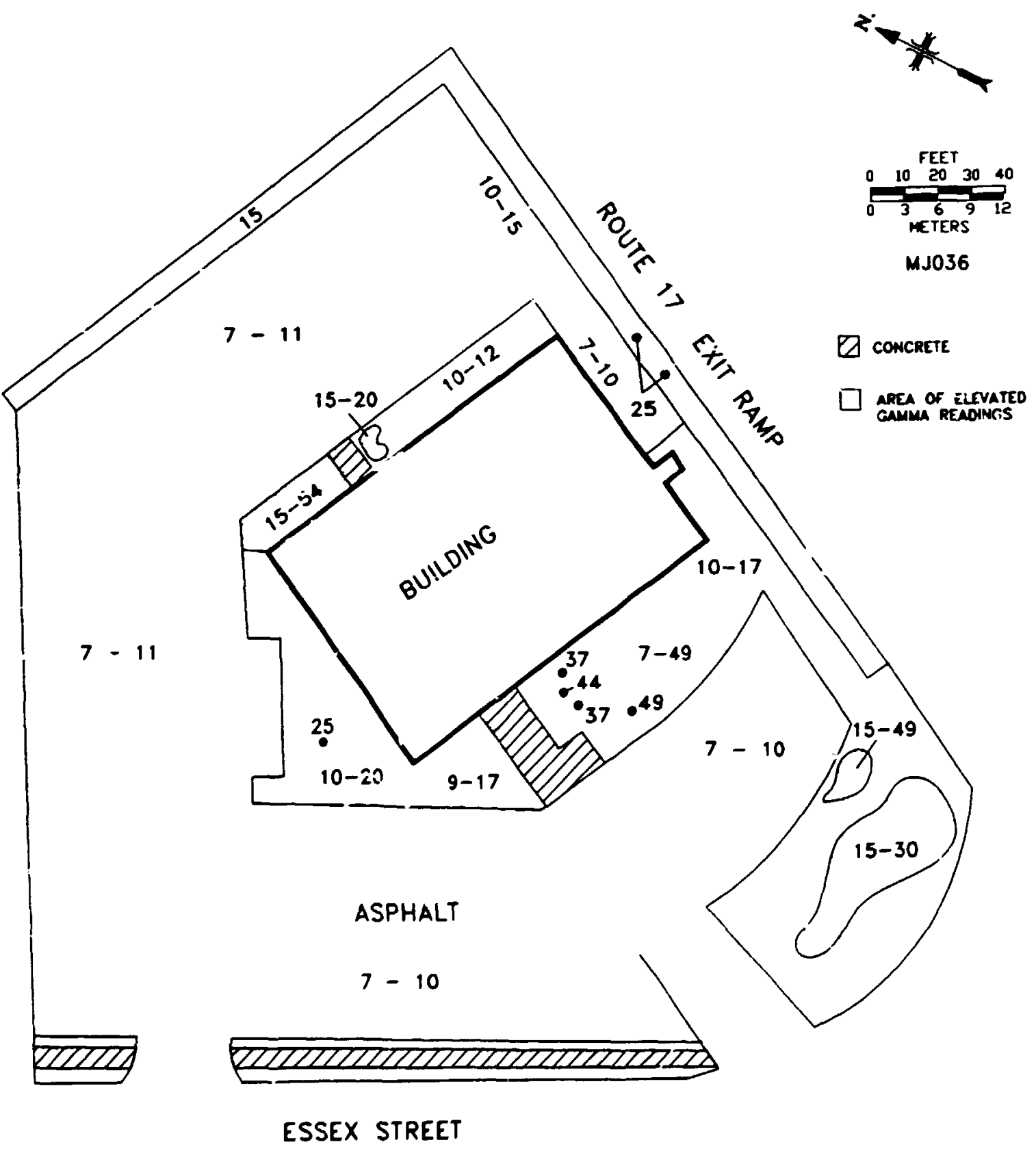

Fig. 1. Gamma radiation levels $(\mu \mathrm{R} / \mathrm{h})$ measured on the surface at Essex Street and State Route 17, Maywood, New Jersey (MJ036). 


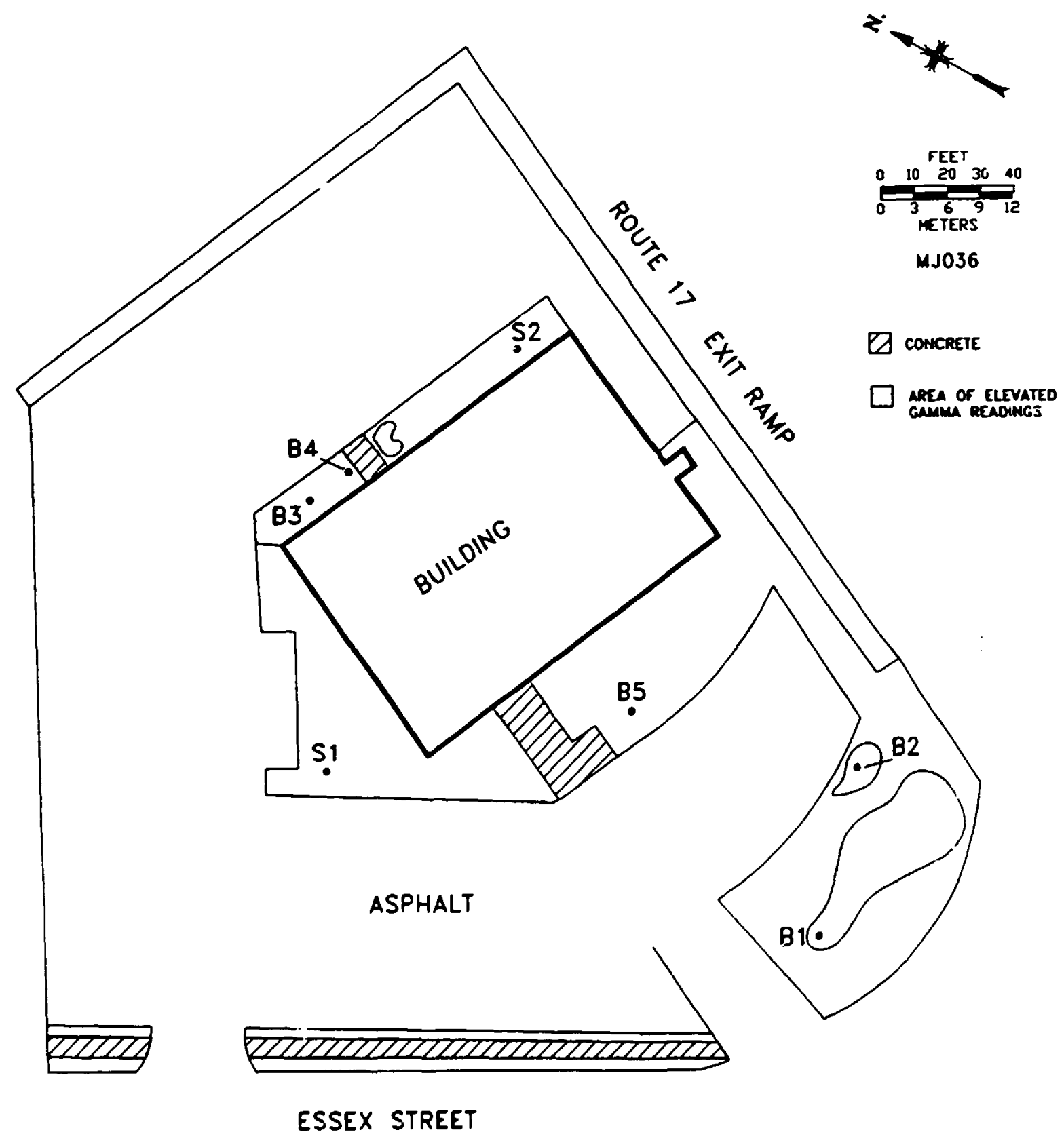

Fig. 2. Diagram showing locations of soil samples taken at Essex Street and State Route 17, Maywood, New Jersey (MJ036). 
Table 1. Applicable guidelines for protection against radiation ${ }^{a}$

\begin{tabular}{|c|c|c|}
\hline Mode of exposure & Exposure conditions & Guideline value \\
\hline $\begin{array}{l}\text { Radionuclide concen- } \\
\text { trations in soil }\end{array}$ & $\begin{array}{l}\text { Maximum permissible con- } \\
\text { centration of the follow- } \\
\text { ing radionuclides in soil } \\
\text { above backgrounc levels } \\
\text { averaged over } 100 \mathrm{~m}^{2} \text { srea } \\
{ }^{232} \mathrm{Th} \\
{ }^{230} \mathrm{Th} \\
{ }^{228} \mathrm{Ra} \\
{ }^{226} \mathrm{Ra}\end{array}$ & $\begin{array}{l}5 \mathrm{pCi} / \mathrm{g} \text { averaged over the } \\
\text { first } 15 \mathrm{~cm} \text { of soil below } \\
\text { the surface; } 15 \mathrm{pCi} / \mathrm{g} \text { when } \\
\text { averaged over } 15-\mathrm{cm} \text { thick } \\
\text { soil layers more than } 15 \mathrm{~cm} \\
\text { below the surface }\end{array}$ \\
\hline
\end{tabular}

¿Reference 3.

Table 2. Background radiation levels for the northern New Jersey area

Type of radiation measurement
or sample $\quad \begin{gathered}\text { Radionuclide level or } \\ \text { radionuclide concentration }\end{gathered}$

Concentration of radionuclides

$\begin{array}{ll}\text { in soil }(\mathrm{pCi} / \mathrm{g}) & \\ { }^{232} \mathrm{Th} & 0.9^{a} \\ { }^{238} \mathrm{U} & 0.9^{a} \\ { }^{226} \mathrm{Ra} & 0.9^{a}\end{array}$

${ }^{a}$ Reference 4. 
Table 3. Concentrations of radionuclides in soil at

Eosnx Street and State Route 17, Maywood, New Jersey (MJ036)

\begin{tabular}{|c|c|c|c|c|}
\hline \multirow{2}{*}{ Sample } & \multirow{2}{*}{$\begin{array}{c}\text { Depth } \\
\text { (cm) }\end{array}$} & \multicolumn{3}{|c|}{ Radionuclide concentration ( $\mathrm{pCi} / \mathrm{g}$ ) } \\
\hline & & ${ }^{226} \mathrm{Ra}^{6}$ & & ${ }^{232} \mathrm{Th}^{6}$ \\
\hline \multicolumn{5}{|c|}{ Systematic samplesf } \\
\hline S1A & $0-15$ & $1.0 \pm 0.06$ & 4.0 & \pm 0.09 \\
\hline S1B & $15-30$ & $1.1 \pm 0.2$ & 4.4 & \pm 0.6 \\
\hline S2A & $0-15$ & $0.59 \pm 0.02$ & 1 & \pm 0.04 \\
\hline S2B & $15-30$ & $0.53 \pm 0.07$ & 0.9 & $2 \pm 0.2$ \\
\hline \multicolumn{5}{|c|}{ Biased samplesd } \\
\hline B1A & $0-15$ & $1.5 \pm 0.05$ & 9.5 & \pm 1 \\
\hline B1B & $15-30$ & $1.4 \pm 0.1$ & 7.1 & \pm 0.3 \\
\hline B1C & $30-45$ & $1.1 \pm 0.1$ & 2.3 & \pm 0.3 \\
\hline B2A & $0-15$ & $2.2 \pm 0.2$ & 11 & \pm 0.7 \\
\hline B2B & $15-30$ & $1.8 \pm 0.6$ & 6.7 & \pm 0.3 \\
\hline B2C & $30-45$ & $1.2 \pm 0.1$ & 2.5 & \pm 0.2 \\
\hline B3A & $0-15$ & $4.6 \pm 1$ & 61 & \pm 3 \\
\hline B3B & $15-30$ & $2.1 \pm 0.3$ & 14 & \pm 2 \\
\hline B4A & $0-15$ & $3.3 \pm 0.2$ & 21 & \pm 2 \\
\hline B4B & $15-30$ & $2.0 \pm 0.2$ & 11 & \pm 0.3 \\
\hline B5A & $0-15$ & $6.0 \pm 0.09$ & 60 & \pm 4 \\
\hline B5B & $15-30$ & $3.1 \pm 0.5$ & 20 & \pm 2 \\
\hline B5C & $30-45$ & $1.9 \pm 0.3$ & 11 & \pm 0.6 \\
\hline
\end{tabular}

-Locations of soil samples are shown on Fig. 2.

'Indicated counting error is at the $95 \%$ confidence level $( \pm 2 \sigma)$.

'Systematic samples are taken at grid locations irrespective of gamma exposure.

${ }^{d}$ Biased samples are taken from areas shown to have elevated ganma exposure rates. 
ORNL/RASA-88/24

\section{INTERNAL DISTRIBUTION}

\author{
1. B. A. Berven \\ 2. R. F. Carrier \\ 3. W. D. Cottrell \\ 4. A. G. Croff \\ 5. J. W. Crutcher \\ 6. J. T. Ensminger \\ 7-11. R. D. Foley
}

12. L. M. Floyd

13. S. V. Kaye

14. P. T. Owen

15-17. R. E. Swaja

18. J. K. Williams

19. IR\&A Publications Office

20. Laboratory Records - RC

\section{EXTERNAL DISTRIBUTION}

21. J. D. Berger, Oak Ridge Associated Universities, P. O. Box 1:7, Oak Ridge, TN 37831

22. R. W. Doane, Eberline, Inc., 800 Oak Ridge Turnpike, Oak Ridge, TN 37831

23. J. J. Fiore, U.S. Department of Energy, 19901 Germantown Road, Germantox a, MD 20874

24-26. P. J. Gross, U.S. Department of Enc :gy, P. O. Box E, Oak Ridge, TN 37831

27-29. G. K. Hovey, Bechtel National, Inc., 800 Oak Ridge Turnpike, Oak Ridge, TN 37831

30. L. R. Levis, Roy F. Weston, Inc., 20030 Century Blvd., Germantown, MD 20874

31. G. P. Turi, U.S. Department of Energy, 19901 Cermantown Road, Germantown, MD 20874

32. J. W. Wagoner, U.S. Department of Energy, 19901 Germantown Road, Germantown, MD 20874

33-35. Andrew Wallo III, U.S. Department of Energy, 19901 Germantown Road, Germantown, MD 20874

36. Office of Assistant Manager, Energy Research and Development, Oak Ridge Operations ')ffice, Oak Ridge, TN 37831

37-38. Office of Scientific, and Technical Information, DOE, Oak Ridge, TN 37831 